Article

\title{
Design of Oligonucleotide Carriers: Importance of Polyamine Chain Length
}

\author{
Vadim V. Annenkov 1,*(D, Uma Maheswari Krishnan ${ }^{2}$, Viktor A. Pal'shin ${ }^{1}$, \\ Stanislav N. Zelinskiy ${ }^{1}$, Gayathri Kandasamy ${ }^{2}$ and Elena N. Danilovtseva ${ }^{1}$ \\ 1 Limnological Institute of the Siberian Branch of the Russian Academy of Sciences, 3, Ulan-Batorskaya St., \\ P.O. Box 278, Irkutsk 664033, Russia; acrom@mail.ru (V.A.P.); jt1233@mail.ru (S.N.Z.); \\ danilovtseva@yahoo.com (E.N.D.) \\ 2 Centre for Nanotechnology \& Advanced Biomaterials (CeNTAB), School of Chemical and Biotechnology, \\ SASTRA University, Thanjavur 613401, Tamil Nadu, India; umakrishnan@sastra.edu (U.M.K.); \\ gayathri.ks86@gmail.com (G.K.) \\ * Correspondence: annenkov@lin.irk.ru; Tel.: +7-914-8982577
}

Received: 22 October 2018; Accepted: 21 November 2018; Published: 23 November 2018

check for updates

\begin{abstract}
Amine containing polymers are extensively studied as special carriers for short-chain RNA (13-25 nucleotides), which are applied as gene silencing agents in gene therapy of various diseases including cancer. Elaboration of the oligonucleotide carriers requires knowledge about peculiarities of the oligonucleotide-polymeric amine interaction. The critical length of the interacting chains is an important parameter which allows us to design sophisticated constructions containing oligonucleotide binding segments, solubilizing, protective and aiming parts. We studied interactions of (TCAG) $n, n=1-6$ DNA oligonucleotides with polyethylenimine and poly(N-(3-((3-(dimethylamino)propyl)(methyl)amino)propyl)- $N$-methylacrylamide). The critical length for oligonucleotides in interaction with polymeric amines is 8-12 units and complexation at these length can be accompanied by "all-or-nothing" effects. New dimethylacrylamide based polymers with grafted polyamine chains were obtained and studied in complexation with DNA and RNA oligonucleotides. The most effective interaction and transfection activity into A549 cancer cells and silencing efficiency against vascular endothelial growth factor (VEGF) was found for a sample with average number of nitrogens in polyamine chain equal to 27 , i.e., for a sample in which all grafted chains are longer than the critical length for polymeric amine-oligonucleotide complexation.
\end{abstract}

Keywords: polymeric amines; oligonucleotides; critical length; grafted polyamines; gene delivery

\section{Introduction}

Gene silencing is a promising approach to combat various diseases including cancer [1-4]. The corresponding techniques include delivery of short nucleic acids (SNA, 13-25 nucleotides) into the cell cytoplasm. Special carriers are employed to protect SNA in circulation, to facilitate SNA penetration into cell and to escape destruction of SNA in lysosomes [5]. Amine containing polymers are extensively studied in this area and the most well-known polymer in this category is polyethylenimine (PEI) [6] which became the reference in gene delivery, but, unfortunately, failed in clinical applications. To improve PEI, it may be derivatized, e.g., with a coordinative module of zinc(II)-dipicolylamine [7]. Among alternatives for PEI, the comb polymers with amine-terminated branches should be mentioned. Their main chains can consist of the sequence of methylene groups entirely, as in acrylic/methacrylic polymers [8], or biodegradable units like polyester [9]. Moreover, highly branched poly $(\beta$-amino ester)s attracted attention due to the combination of high gene transfection efficiency and low cytotoxicity [10-13]. Another way of upgrading polyplexes is involvement of a third uncharged 
component, e.g., multifunctional oligomers based on a lactose derivative, $N$-isopropyl acrylamide and 1-vinylimidazole and functionalized with small ligands (folate, glutathione, cysteine and arginine) endowed the formulated ternary complexes with great properties suitable for transfection [14]. High buffer capacity of PEI at pH 6-7.5 causes escape of the polymer-SNA complex from endosomes by the "proton pump" mechanism. The other requirement for SNA carriers is low cytotoxicity which is a limitation of polymeric amines. Dedicated design of the oligonucleotide carriers requires knowledge about peculiarities of SNA-polymeric amine interaction. This interaction is a typical interpolymeric reaction $[15,16]$ and one of the important parameters of these reactions is the critical length $\left(L_{c}\right)$ of the interacting chains. Sub-optimal length results in weak interactions while higher $L_{c}$ results in relatively irreversible reactions. The importance of $L_{c}$ value in SNA-polymer interactions was addressed in several articles [17-20]. Synthetic polymeric amines of various length and SNA of a fixed length have been explored in several earlier reports $[17,18]$ but the set of amine chains investigated was restricted. A recent work had investigated a set of SNA with varying chain length [19] and the minimal length of the SNA chain was determined as 14 nucleotides in reaction with virus particle of unknown chemical structure. A study of polylysine interaction with plasmid DNA [20] revealed that complexation occurred at 8 lysine units and an absence of interaction was observed with samples with 3 lysine units. The lack of information about $L_{\mathcal{c}}$ in SNA-polymeric amine interactions stems from the fact that the main objective of studies in the field of gene therapy has focused on achieving complexation using SNA with definite length, usually near 20 nucleotides. However, polymeric constructs for SNA delivery often contain combinations of short amine, neutral and sometimes acidic sequences and hence information about $L_{c}$ values is required for the design of these constructs and understanding their properties.

Our work has two objectives with the first being estimation of $L_{c}$ for DNA oligonucleotides in the reaction with PEI and new polymeric amine poly(N-(3((3(dimethylamino)propyl)(methyl)amino)propyl)Nmethylacrylamide) (AKX-182, Scheme 1) [21]. We have used the DNA oligonucleotides $(\mathrm{TCAG})_{n}$, where $n=1-6$, which contain equal amount of the each nucleotide and cannot form stable hairpins or self-dimers. The second objective of our work is to synthesize and study new polymers as gene delivery agents. These polymers originate from bioinspired polymers with grafted polyamine chains [22]. Polyamines containing 3-4 nitrogen atoms, including spermine and spermidine, play an important role in cell physiology: protein and nucleic acid synthesis, gene expression, protection from oxidative damage and etc. [23]. The so-called long-chain polyamines (LCPAs), more exactly oligomeric polyamines, have been found in bacteria [24], diatom algae [25], in the siliceous sponge [26] and in haptophyte [27]. In the case of diatoms, LCPAs are present as post-translationally grafted side chains in specific proteins namely, silaffins [28]. These LCPAs contain up to two tens of partially methylated nitrogen atoms separated by trimethylene or tetramethylene fragments [29]. Some polymeric amines [30,31] capable of interacting with oligomers of silicic acid and forming stable composite nanoparticles were considered as models of cytoplasmic silicon containing vesicles. We have elaborated [32] a method to synthesize LCPAs as an oligomeric mixture containing polyamines with 6-30 nitrogen atoms. Grafting of the LCPA chains on to poly(acrylic acid) resulted in polyampholytes which can control condensation of silicic acid giving rise to silica, the structure of which was similar to biogenic silica [33]. Neutral polymers with pendant LCPAs can interact with SNA and the obtained complexes are promising particles for gene therapy [22]. Medical applications of polymers require homogeneous macromolecules and in this work we synthesized poly $(N, N$-dimethylacrylamide) (PDMAAm) containing grafted LCPA chains starting from narrow polymer and LCPA fractions (Scheme 1). Influence of the length of pendant LCPA chains on the capability to interact with SNA was investigated taking into account $L_{\mathcal{c}}$ values for SNA. 


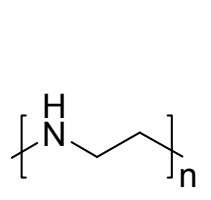

PEI<smiles>CCC(CC)C(=O)N(C)CCCN(C)CCCN(C)C</smiles>

AKX-182

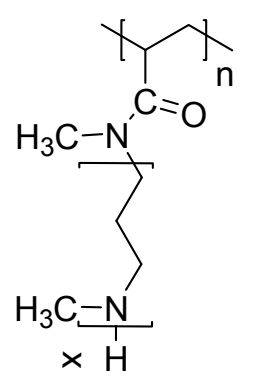<smiles>CC(C)C(=O)N(C)C</smiles>

Scheme 1. Structures of the studied polymers.

\section{Materials and Methods}

\subsection{Materials}

2,2'-Azobis(2-methylpropionitrile) (AIBN) (Sigma-Aldrich, St. Louis, MO, USA) was recrystallized from ethanol prior to use. Diethyl ether (Acros, Geel, Belgium) and 1,4-dioxane (Sigma-Aldrich) were distilled under sodium. Dimethylformamide (DMF) (Sigma-Aldrich) was dried with CuSO4 (30 min) and distilled at $5 \mathrm{~mm} \mathrm{Hg}$. Acryloyl chloride (Sigma-Aldrich) was distilled before polymerization. Dichloromethane (Acros, Geel, Belgium) was refluxed over phosphorus pentoxide and distilled under argon. Dimethylamine $40 \mathrm{wt} \%$ aqueous solution, triethylamine, 1,3-dibromopropane, $\mathrm{N}$-hydroxysuccinimide, $\mathrm{N}$-hydroxyphthalimide, potassium hydroxide, potassium carbonate of reagent grade (Sigma-Aldrich, Fisher, or Acros Chemicals) were used in the study. Dimethyl sulfoxide-d6 (DMSO-d6, 99.8 atom D \%), deuterochloroform (99.8 atom D \%), heptafluorobutyric acid (HFBA, $\geq 99.0 \%$ (GC)), acetonitrile (HPLC Far UV/gradient grade, Avantor Performance Materials B.V., Deventer, The Netherlands) and trifluoroacetic acid (TFA, 99 wt \% purity) were purchased from Sigma-Aldrich (St. Louis, MO, USA), Fisher (Hampton, NH, USA), or Acros (Geel, Belgium) chemicals and used without further treatment. A $9.01 \mathrm{wt} \%$ solution of dimethylamine in 1,4-dioxane was prepared via saturation of dry 1,4-dioxane with gaseous dimethylamine. The amine concentration was determined from the resulted weight gain as well as with potentiometric titration. To obtain gaseous dimethylamine, its $40 \mathrm{wt} \%$ aqueous solution was added dropwise to a large excess of potassium hydroxide flakes. The evolved gas was passed through a drying column packed with $\mathrm{KOH}$ flakes.

$\mathrm{N}, \mathrm{N}$-bis[3-(methylamino)propyl]methylamine was prepared following the technique from our earlier work [34]. Oligo( $N$-methylazetidine) (LCPA, ZS-309 sample) was prepared from 1,3-dibromopropane and $\mathrm{N}, \mathrm{N}$-bis[3-(methylamino)propyl]methylamine according to earlier work from our group [32]. AKX-182 polymer was prepared according to the protocol described earlier [21]. PEI $\left(\mathrm{M}_{\mathrm{w}}=30,000-40,000\right)$ was obtained from SERVA Fine Biochemica (Heidelberg, Germany).

FAM 3'-tagged DNA oligonucleotides were purchased from Evrogen JSC, Russia. Small interfering RNA (si-RNA) against vascular endothelial growth factor (VEGF) was obtained from Eurofins Genomics, Louisville, KY, USA. The sequence of the sense and anti-sense strands of the fluorophore-tagged si-RNA is as follows: sense-Cy3-GGAGUACCCUGAUGAGAUC and antisense: CCUCAUGGGACUACUCUAG-Cy3.

\subsection{Instrumentation}

${ }^{1} \mathrm{H}$ nuclear magnetic resonance (NMR) spectra were obtained on a DPX 400 Bruker instrument (400.13 MHz, Billerica, MA, USA) in $\mathrm{CDCl}_{3}$ and DMSO-d $\mathrm{d}_{6}$. Spectra of LCPA were recorded for $\mathrm{CDCl}_{3}$ solutions, whereas those of poly(N,N-dimethylacrylamide)s grafted with LCPA were obtained for DMSO- $\mathrm{d}_{6}$ solutions of samples derivatized with trifluoroacetic acid as follows: to a sample of polymer, typically of ca. $30 \mathrm{mg}$, in a glass screw cap flat-bottom vial, $500 \mu \mathrm{L}$ of TFA was added. The vessel was heated at about $50^{\circ} \mathrm{C}$ and occasionally shaken for about $30 \mathrm{~min}$ to ensure complete dissolution. Then, excess TFA was removed to dryness at $50{ }^{\circ} \mathrm{C}$ with argon flow. The cooled residue was mixed 
with $600 \mu \mathrm{L}$ of DMSO-d6 and left overnight at room temperature. The resultant solution was filtered through a cotton pad in a $1 \mathrm{~mL}$ polypropylene pipette tip directly to a NMR ampoule.

Mass spectrometric analysis was performed on an Agilent 6210 TOF LC/MS System. The samples were dissolved in acetonitrile. Water and acetonitrile with $0.1 \%(v / v)$ HFBA were used as eluting solvents A and B, respectively (Solvent A-90\%, B-10\%). The flow rate of the mobile phase was set at $0.2 \mathrm{~mL} / \mathrm{min}$, while the injection volume of sample solution was $20 \mu \mathrm{L}$. The conditions for TOF MS were as follows: the mass range was $m / z 100-1000$ and scan time was $1 \mathrm{~s}$ with an interscan delay of $0.1 \mathrm{~s}$; mass spectra were recorded under ESI+, V mode, centroid, normal dynamic range, capillary voltage $3500 \mathrm{~V}$, desolvation temp $350{ }^{\circ} \mathrm{C}$, nitrogen flow $5 \mathrm{~L} / \mathrm{min}$.

The molecular masses of the new polymers were estimated via size-exclusion chromatography (SEC) using a Milichrom A02 chromatograph (JSC Econova, Novosibirsk, Russia) with $2 \mathrm{~mm} \times 75 \mathrm{~mm}$ column filled with SRT SEC-100 $5 \mu \mathrm{m}$ phase (Sepax Technologies, Inc., Newark, NJ, USA), operated at $35^{\circ} \mathrm{C}$ using phosphate buffer solution $0.15 \mathrm{M}, \mathrm{pH}$ 6.86. The flow rate of the mobile phase was set at $0.03 \mathrm{~mL} \cdot \mathrm{min}-1$ (pressure $100 \mathrm{psi}$ ), whereas the injection volume for $1 \mathrm{~g} \cdot \mathrm{L}^{-1}$ of the sample solution was $1 \mu \mathrm{L}$. Fractionated samples of poly(vinyl formamide) [35] were applied as standards $\left(\mathrm{M}_{\mathrm{w}} / \mathrm{M}_{\mathrm{n}}<1.3\right)$.

Zeta-potential $(\zeta)$ and hydrodynamic radius $\left(R_{h}\right)$ were measured at $25{ }^{\circ} \mathrm{C}$ with a Zetasizer Nano-ZS ZEN3600 (Malvern Instruments Ltd., Worcestershire, UK), equipped with a $4 \mathrm{~mW}$ He-Ne laser operating at $\lambda_{o}=633 \mathrm{~nm}$. Measurements were performed at $\theta=173^{\circ}$ in zeta-potential-DTS1060 folded capillary cells. Calculation of $\zeta$ and $R_{h}$ values was performed using software supplied with the Zetasizer.

Transmission electron microscopy (TEM) of the polymer-DNA complexes was performed using a LEO 906E instrument on solutions diluted tenfold just before freezing. The solutions were placed on formvar film coated copper grids and air dried.

Atomic force microscopy (AFM) was performed using Scanning Probe Microscope CMM-2000 (PROTON-MIET, ZAVOD, JSC, Zelenograd, Russia) operated in contact mode in air at room temperature using silicon probes (nominal probe curvature radius of $10 \mathrm{~nm}$ ). Height mode images $(512 \times 512$ pixels) were collected with a scan speed between 1 and $2 \mathrm{~Hz}$. The samples were placed on mica slips, water was removed with a filter paper after $30 \mathrm{~min}$ and slips were air dried. The software package Gwyddion was used for AFM image processing.

\subsection{Synthesis of Poly(N,N-dimethylacrylamide) with Grafted LCPA Chains (ZS-371-n)}

\subsubsection{Synthesis of Poly(acryloyl chloride) (PAC)}

PAC was synthesized similar to the protocol described earlier [36] by polymerization of acryloyl chloride $(6.336 \mathrm{~g}, 0.070 \mathrm{~mol})$ in $25 \mathrm{~mL}$ of dioxane with the addition of $0.1267 \mathrm{~g}$ AIBN in argon atmosphere at $60{ }^{\circ} \mathrm{C}$ for $48 \mathrm{~h}$. PAC was precipitated from the reaction solution using $138 \mathrm{~mL}$ of cyclohexane. The supernatant was decanted and the residue was dissolved in DMF (Solution A, see below) for further use. With the objective to estimate yield and polymerization degree of the PAC, the reaction mixture was poured into water $(50 \mathrm{~mL})$ and dialyzed against water. After freeze drying, poly(acrylic acid) was obtained with $90 \%$ yield. According to viscometry data, [37] the polymerization degree of the poly(acrylic acid) and, correspondingly of PAC, was found to be 220.

2.3.2. Preparation of $\operatorname{Poly}(\mathrm{N}, \mathrm{N}$-dimethylacrylamide-co- $N$-acryloxysuccinimide) (ZS-358)

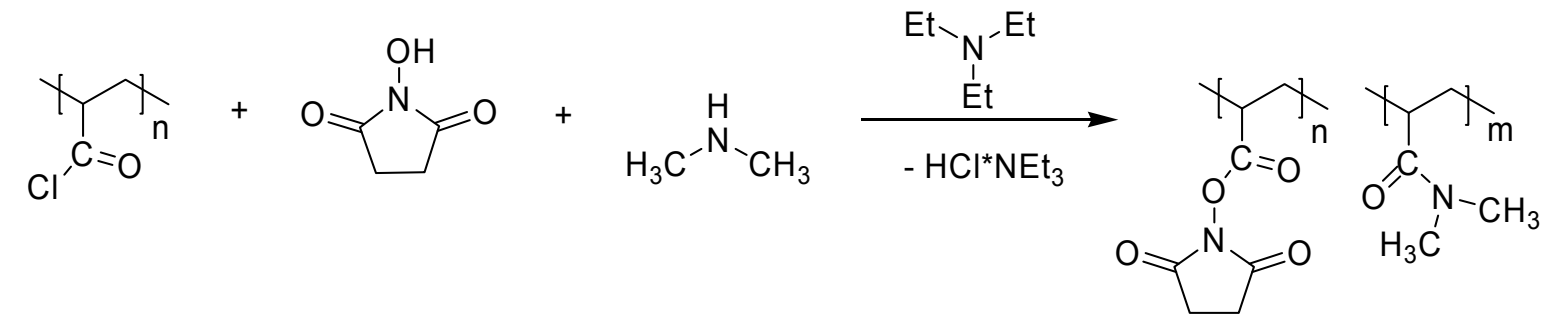


Three initial solutions namely Solution A (The prepared PAC in $104.4 \mathrm{~g}$ of DMF), Solution B ( $N$-hydroxysuccinimide $(1.61 \mathrm{~g}, 14.0 \mathrm{mmol})$ and triethylamine $(1.70 \mathrm{~g}, 16.8 \mathrm{mmol})$ dissolved in $11 \mathrm{~g}$ of DMF), and Solution C (Triethylamine (7.22 g, 71.4 mmole), $10.1 \mathrm{wt.} \%$ dimethylamine solution in 1,4-dioxane (26.55 g, corresponds to $59.48 \mathrm{mmol}$ of $\mathrm{HN}(\mathrm{CH} 3) 2)$ and $22.9 \mathrm{~g}$ of DMF) were combined.

Solution B was added to magnetically stirred solution A (cooling on an ice bath) for eight minutes. The mixture was kept stirred with cooling for $31 \mathrm{~min}$ followed by dropwise addition of solution $\mathrm{C}$ for $30 \mathrm{~min}$. Stirring was continued with cooling for $30 \mathrm{~min}$ and then at room temperature for two hours. The reaction vessel was left in a refrigerator for about $15 \mathrm{~h}$. The white precipitate was filtered off using a filter funnel with sintered glass disc. The light yellowish filtrate was concentrated to a volume of $10-15 \mathrm{~mL}$ under vacuum at room temperature. Addition of $110 \mathrm{~mL}$ of toluene precipitated a yellow sticky mass which was washed with toluene $(50 \mathrm{~mL} \times 1)$, THF $(25 \mathrm{~mL} \times 2)$ and dried using an oil vacuum pump for four hours to yield $7.496 \mathrm{~g}$ of ZS-358.

\subsubsection{Fractional Precipitation of ZS-358}

A solution of ZS-358 (6.434 g) in $26 \mathrm{~mL}$ of $\mathrm{CH}_{2} \mathrm{Cl}_{2}$ was filtered through a glass disc (10-15 $\left.\mu \mathrm{m}\right)$ and diluted to a total volume of $215 \mathrm{~mL}$ with $\mathrm{CH}_{2} \mathrm{Cl}_{2}$. The first fraction (1F) was precipitated with careful addition of $19.64 \mathrm{~g}$ of n-hexane to the stirred solution. The supernatant was decanted in about $90 \mathrm{~min}$ for the successive precipitations (Table 1).

Table 1. Fractionation of ZS-358.

\begin{tabular}{cccc}
\hline Fraction \# & Portion of $\mathbf{n}$-Hexane, $\mathbf{g}$ & Precipitation time & Weight of dried fraction, $\mathbf{g}$ \\
\hline 1F & 19.64 & $1.5 \mathrm{~h}$ & $-^{*}$ \\
2F & 24.38 & $0.5 \mathrm{~h}$ & 0.6449 \\
3F & 23.79 & over night & 1.2384 \\
4F & 15.36 & over night & 0.7422 \\
5F & 18.93 & over night & 0.7243 \\
6F & 21.52 & over night & 0.8777 \\
7F & 34.39 & over night & 0.5444 \\
\hline
\end{tabular}

* 1F was unsuitable for the further usage because of poor solubility in organic solvents. Fractions 3-7 were precipitated from solutions kept in a refrigerator.

\subsubsection{Preparative Exclusion Chromatography (SEC) Fractionation of ZS-309}

The fractionation was performed on a glass jacketed chromatography column $(0.7 \mathrm{~cm} \times 85 \mathrm{~cm})$ packed with Sephadex G-25 (coarse, 100-300 $\mu \mathrm{m}$ ). A solution of $100 \mathrm{mg}$ of ZS-309 in $200 \mu \mathrm{L}$ of $0.1 \mathrm{M} \mathrm{HCl}$ was loaded on the wet sorbent surface followed by gravity elution at $35^{\circ} \mathrm{C}$ with a $25 \mathrm{mM}$ acetate buffer solution containing $0.2 \mathrm{M} \mathrm{NaCl}$. Collected fractions were analyzed by silica gel TLC $\left(\mathrm{CH}_{2} \mathrm{Cl}_{2}: \mathrm{CH}_{3} \mathrm{OH}: 25 \%\right.$ aq. $\left.\mathrm{NH}_{3}=2: 2: 1\right)$. The spots were visualized in red color by Dragendorff's reagent [38]. Chosen fractions were combined and analyzed with LC-MS (Figure S1) with the objective to estimate effectiveness of the fractionation. Then, the solutions were evaporated to dryness under vacuum, mixed with a solution of $\mathrm{K}_{2} \mathrm{CO}_{3}(50 \%)$ in water and extracted with $\mathrm{CH}_{2} \mathrm{Cl}_{2}$. The extracts were dried over anhydrous potassium carbonate, evaporated and finally kept under vacuum of an oil pump for two days. The obtained LCPA fractions contain 27.6 (ZS-309-1), 16.3 (ZS-309-2), 13.4 (ZS-309-3) nitrogen atoms in molecule as determined with ${ }^{1} \mathrm{H}$ NMR (Figure S2) with the use signals at $2.40 \mathrm{ppm}$ (terminal methyl groups) and $2.16 \mathrm{ppm}$ (methyl groups in the polyamine chain). 
2.3.5. Grafting of Oligo( $N$-methylazetidine) onto $\operatorname{Poly}(N, N$-dimethylacrylamide-co- $N$ acryloxysuccinimide) (ZS-371-n)<smiles>CC(C)CC(CC(C)C(=O)ON1C(=O)CCC1=O)C(=O)N(C)C</smiles>

Fractions of ZS-358<smiles>[X]C([X])(C)N(C)CCCC(C)NC</smiles>

2. Capping with $\mathrm{HN}\left(\mathrm{CH}_{3}\right)_{2}$

- N-hydroxysuccinimide<smiles>CCCN(C)C(=O)C(C)CCCCC(C)C(=O)N(C)C</smiles>

Preparation of ZS-371-1. ZS-309-3 (0.06602 g), a fraction of oligo( $N$-methylazetidine), was dissolved in a mixture of $0.70 \mathrm{~g}$ of DMF and $1.02 \mathrm{~g}$ of $10.8 \% \mathrm{HN}\left(\mathrm{CH}_{3}\right)_{2}$ in 1,4-dioxane (1-st portion) followed by addition of $0.24958 \mathrm{~g}$ of $3 \mathrm{~F}$ (a ZS-358 fraction) solution in $1.83 \mathrm{~g}$ of DMF. The solution was purged with argon, sealed in a glass vessel and kept at $60^{\circ} \mathrm{C}$ for $24 \mathrm{~h}$. After that, the 2-nd portion of the dimethylamine solution $(0.38 \mathrm{~g})$ was added and heating continued for additional $24 \mathrm{~h}$. Then, the mixture was rotary evaporated and further kept under vacuum of an oil pump at room temperature for $3 \mathrm{~h}$. The sticky residue was thoroughly triturated with diethyl ether multiple times, the ether solutions discarded and the product reprecipitated three times from methylene chloride/methanol to ether. After vacuum drying, the polymer was dissolved in deionized water, filtered through a $0.45 \mu \mathrm{m}$ cellulose acetate membrane and freeze-dried to give $0.222 \mathrm{~g}$ of ZS-371-1.

The other polymers ZS-371-(2-7) were prepared similarly, see the Table 2.

The content of grafted units was calculated from ${ }^{1} \mathrm{H}$ NMR spectra (Figure S3) of TFA-derivatized samples dissolved in DMSO- $\mathrm{d}_{6}$ [39]. The integral intensities of the $1 \mathrm{H}$ NMR signal at $10.4 \mathrm{ppm}$ (protons at tertiary nitrogen atoms) were compared with the integral intensities of the all C-H protons within 0.8-4.6 ppm except for those of DMSO, keeping in mind the average length of the grafted oligoamines.

Table 2. Grafting of oligo( $N$-methylazetidine) onto fractions of ZS-309.

\begin{tabular}{|c|c|c|c|c|}
\hline Item & ZS-371-1 & ZS-371-2 & ZS-371-3 & ZS-371-5 \\
\hline Fraction of ZS-358 & $3 \mathrm{~F}$ & $3 \mathrm{~F}$ & $3 \mathrm{~F}$ & $4 \mathrm{~F}$ \\
\hline Amount, g & 0.24958 & 0.51380 & 0.19950 & 0.31191 \\
\hline DMF for dissolving ZS-358, $\mathrm{g}$ & 1.83 & 3.37 & 3.37 & 2.95 \\
\hline Oligo( $N$-methylazetidine) fraction & ZS-309-3 & ZS-309-2 & ZS-309 & ZS-309-1 \\
\hline Length of the Oligo( $N$-methylazetidine) & 13.4 & 16.3 & 15.5 & 27.6 \\
\hline Amount, $g$ & 0.06602 & 0.25028 & 0.07295 & 0.26000 \\
\hline 1-st portion of $10.8 \% \mathrm{HN}\left(\mathrm{CH}_{3}\right)_{2}$ in 1,4-dioxane, $\mathrm{g}$ & 1.02 & 2.10 & 0.81 & 1.27 \\
\hline 2-nd portion of $10.8 \% \mathrm{HN}\left(\mathrm{CH}_{3}\right)_{2}$ in 1,4-dioxane, $\mathrm{g}$ & 0.38 & 0.45 & 0.49 & 0.43 \\
\hline Yield of copolymer, $g$ & 0.22189 & 0.42537 & 0.16356 & 0.32097 \\
\hline $\mathrm{M}_{\mathrm{n}}, \mathrm{kDa}$ & 11.0 & 11.4 & 11.9 & 8.6 \\
\hline $\mathrm{M}_{\mathrm{w}} / \mathrm{M}_{\mathrm{n}}$ & 1.24 & 1.22 & 1.36 & 1.16 \\
\hline Grafting degree, $\%$ & 1.8 & 3.0 & 2.3 & 3.4 \\
\hline
\end{tabular}

\subsection{Study of Polymer-Oligonucleotide Interactions and In Vitro Activity of the Polyplexes}

\subsubsection{Interaction with DNA Oligonucleotides}

The interaction between DNA oligonucleotides and polymers was investigated by electrophoresis on agarose gel. Complexes were prepared by mixing solutions of the polymer and oligonucleotide. The samples were incubated at room temperature for $30 \mathrm{~min}$ and placed into the wells of the $1 \%$ agarose gel. Free oligonucleotide, as a control, was also loaded onto the gel. The gel running buffer was $40 \mathrm{mM}$ Tris acetate (adjusted to $\mathrm{pH}$ 7.4) and $1 \mathrm{mM}$ EDTA. A glycerol gel loading buffer was used 
( $0.5 \%$ sodium dodecyl sulfate, $0.1 \mathrm{M}$ EDTA $(\mathrm{pH}=8)$, and $50 \%$ glycerol for $10 \times$ reagent). The gel was run at $90 \mathrm{~V}$ and the fluorescein-tagged oligonucleotide was visualized on a UV transilluminator.

\subsubsection{RiboGreen Assay}

Polyplexes were prepared in the ratio of $4: 1$ and diluted to $100 \mu \mathrm{L}$ with deionized water in a 96-well plate. $100 \mu \mathrm{L}$ of 1:1000 diluted ribogreen dye (Invitrogen, Carlsbad, CA, USA) was added to each well and the fluorescence intensity was measured using a multimode reader (Synergy H1, Biotek, Winooski, VT, USA) following incubation for $5 \mathrm{~min}$ in dark. The sample was excited at $490 \mathrm{~nm}$ and the emission was measured at $525 \mathrm{~nm}$.

\subsubsection{Study of the Polymer and Polyplex Toxicity}

Toxicity of the polymer and polyplex was evaluated using (3-(4, 5-dimethylthiazol-2-yl)-5-(3carboxymethoxyphenyl)-2-(4-sulfophenyl)-2H-tetrazolium) MTS assay (Cell Titer 96 Aqueous one solution, Promega, Madison, WI, USA). Four thousand A549 cells per well were seeded in a 96-well plate and incubated at $37^{\circ} \mathrm{C}$ in $5 \% \mathrm{CO}_{2}$. After the cells achieved confluency, the medium was removed and washed with PBS ( $\mathrm{pH}$ 7.4) to remove the non-adherent cells. Polyplexes were prepared by mixing $10 \mu \mathrm{M}$ siRNA (Eurofins, Louisville, KY, USA) with $4 \mathrm{mg} / \mathrm{mL}$ polymer solution in 1:4 ratio. Then, $5 \mu \mathrm{L}$ of the polyplex or $2 \mathrm{mg} / \mathrm{mL}$ polymer solution was mixed with $100 \mu \mathrm{L}$ of serum-free media and added to the cells. After $4 \mathrm{~h}$, the medium was replaced with the fresh medium and incubated for $24 \mathrm{~h}$ or $48 \mathrm{~h}$. MTS reagent (Promega, Madison, WI, USA, $10 \mu \mathrm{L}$ ) and $100 \mu \mathrm{L}$ of serum-free media was added to each sample well and incubated at $37^{\circ} \mathrm{C}$ for $2 \mathrm{~h}$. The reaction was stopped by addition of $25 \mu \mathrm{L}$ of $10 \%$ sodium dodecyl sulfate (SDS) solution. The absorbance was measured at $490 \mathrm{~nm}$ using multimode reader (Synergy H1, Biotek, Winooski, VT, USA).

\subsubsection{Study of the Polyplex Internalization}

These studies were carried out with a polymer concentration of $4 \mathrm{mg} / \mathrm{mL}$ and a siRNA concentration of $10 \mu \mathrm{M}$ with a polymer to siRNA ratio of 4:1. The internalisation of the polyplex in A549 cells was evaluated using fluorescent siRNA (Eurofins) that is excited at $538 \mathrm{~nm}$ and emits at $640 \mathrm{~nm}$. A549 cells were cultured in DMEM (GIBCO, Thermo Fisher Scientific, Waltham, MA, USA) on a cover slip in a 6-well plate with a seeding density $10^{5}$ cells/well. After the cells attained confluency, the medium was removed and washed with phosphate buffered saline (PBS, $\mathrm{pH}$ 7.4) to remove the non-adherent cells. Then, $5 \mu \mathrm{L}$ of polyplexes were added to $200 \mu \mathrm{L}$ of serum-free media and incubated for specific time points. The medium was then replaced with fresh medium containing fetal bovine serum (GIBCO, Thermo Fisher Scientific, Waltham, MA, USA). The cells were stained with Hoechst 33342 (Invitrogen, Carlsbad, CA, USA) and the images were captured using laser scanning confocal microscopy (FV1000, Olympus, Tokyo, Japan).

\subsubsection{Western Blot Study of VEGF Silencing}

For performing Western blot, total protein was isolated from the A549 cells using cell lysis buffer that contains a cocktail of RIPA buffer, PMSF, protease and protease inhibitors (Cell Signalling, Danvers, MA, USA). The isolated protein was quantified using Lowry's method. An aliquot containing $50 \mathrm{mg}$ protein was subjected to electrophoresis using 12\% SDS-PAGE (sodium dodecyl sulfate-polyacrylamide gel electrophoresis). The protein bands were transferred to PVDF membrane at $4{ }^{\circ} \mathrm{C}$ for $1 \mathrm{~h}$ in the presence of transfer buffer containing tris-glycine. Non-specific binding was eliminated using a blocking agent of $5 \%$ skimmed milk in Tris-buffered saline containing $0.1 \%$ Tween- 20 . The membrane was incubated overnight with primary antibody (VEGF antibody, dilution 1:500, Santa Cruz, CA, USA) at $4{ }^{\circ} \mathrm{C}$. The blots were then washed with tris-glycine buffer followed by incubation with anti-mouse horseradish peroxidase-conjugated secondary antibody (dilution 1:5000, Cell Signalling, Danvers, MA, USA) for $1 \mathrm{~h}$ at room temperature. The protein bands were visualized using Tetramethyl benzidine/hydrogen peroxide (TMB $/ \mathrm{H}_{2} \mathrm{O}_{2}$, Bio-Rad, Hercules, CA, USA) reagent 
following manufacturer's protocol and the images were captured using gel documentation system (Chemidoc, Bio-Rad, Hercules, CA, USA). The housekeeping gene beta actin was visualized after stripping the membrane following which the membrane was reblocked and re-incubated with anti-beta actin primary antibody (Cell Signalling, Danvers, MA, USA). Quantity-one software was used for analysis of the images and the band intensities were calculated. After background normalization, beta-actin band intensity was used to normalize the band intensity of the VEGF protein band.

\section{Results and Discussion}

\subsection{Determination of Critical Length of DNA Sequence in Reaction with Polymeric Amines}

The influence of length of single-strand DNA oligonucleotide on the ability to interact with PEI and AKX-182 was studied at an N/P ratio (ratio of amine groups to nucleotides) equal to 20 . The high excess of polymeric amine minimizes stacking and other possible side effects. Gel electrophoresis data (Figure 1) show formation of slightly positive complex with 12-24-mer DNA for PEI and 16-24 mer DNA in the case of AKX-182. Decreasing the DNA length to 8-12 units results in a diffuse spot which corresponds to some negative-charged complexes. 4-mer DNA does not interact with PEI and AKX-182. The formation of negative-charged products is unexpected, poor interaction of short oligonucleotides with polymeric amines could result in the presence of free DNA but the observed diffuse spots are far from free DNA position. Here, we see two kinds of DNA-containing particles: neutral (or slightly positive) and negative charged. These complexes were observed at various N/P ratios and DNA length (Table 3). Increasing the DNA length and N/P ratio results in disappearance of the negatively charged complex. Nucleic acids can interact with amines by the means of ionic interactions through phosphate groups or by hydrogen bonds through nucleobases $[40,41]$ and references in this review. The latter mechanism suggests that the negatively charged free phosphate groups compensates the positive charge of the free amine units. We can hypothesize formation of negatively charged coordinated regions surrounded by positively charged parts of the polymer (Scheme 2a). Increase in the polymeric amine content results in the presence of a positively charged complex only. The formation of only negative particles with short DNA chains is possibly due to the "all-or-nothing" scheme (Scheme 2b) which is often realized with weak associative interactions [42,43]. Experiments with double stranded DNA (Figure 2) show similar behavior of the DNA-polymer complexes.

Thus, 8-12 nucleotides represent a critical length of DNA chains at which interaction with polymeric amines proceeds under high excess of the amine and is accompanied by "all-or-nothing" effects.

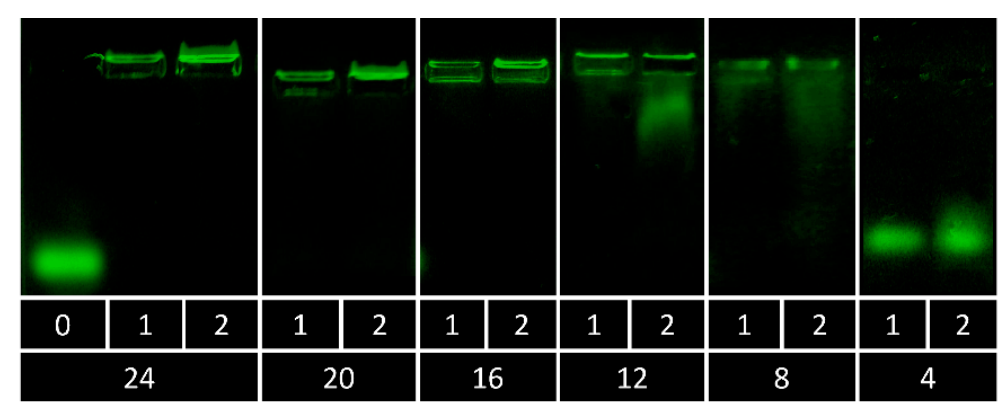

Figure 1. Gel electrophoresis data for PEI (1) and AKX-182 (2) complexes with (TCAG)n DNA (last row-length of the DNA), "0"-free DNA (similar blots were observed irrespective of DNA length). DNA concentration was $2.5 \mu \mathrm{M}$ (calculating on DNA chains), $\mathrm{N} / \mathrm{P}$ ratio $=20$. 


$$
\text { Long oligonucleotides }
$$

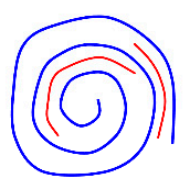

Neutral or slightly positive complex

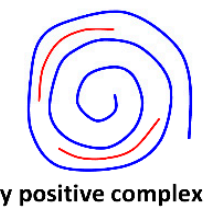

Molymeric amine

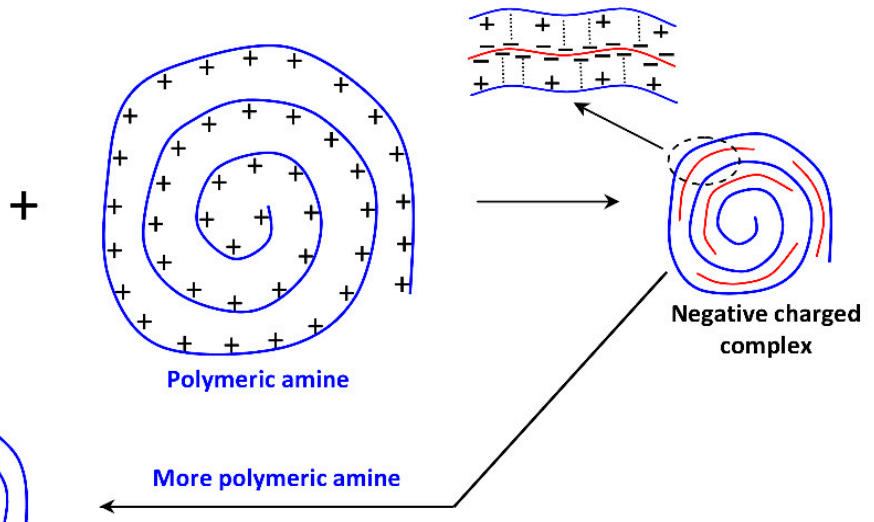

(a)

\begin{tabular}{|c|c|c|c|c|c|c|c|c|c|c|}
\hline \multirow{3}{*}{ DNA length } & \multicolumn{10}{|c|}{ N/P Ratio } \\
\hline & \multicolumn{5}{|c|}{ PEI } & \multicolumn{5}{|c|}{ AKX-182 } \\
\hline & 5 & 10 & 20 & 40 & 80 & 5 & 10 & 20 & 40 & 80 \\
\hline 4 & $\mathrm{~N}$ & $\mathrm{~N}$ & $\mathrm{~N}$ & $\mathrm{~N}$ & $\mathrm{~N}$ & $\mathrm{~N}$ & $\mathrm{~N}$ & $\mathrm{~N}$ & $\mathrm{~N}$ & $\mathrm{~N}$ \\
\hline 8 & $\mathrm{~N}$ & - &,-+ &,-+ & + & $\mathrm{N}$ & - &,-+ &,-+ & + \\
\hline 12 &,-+ &,-+ & + & + & + & - & - &,-+ & + & + \\
\hline 16 &,-+ &,-+ & + & + & + &,-+ &,-+ & + & + & + \\
\hline 20 &,-+ &,-+ & + & + & + &,-+ &,-+ & + & + & + \\
\hline 24 &,-+ &,-+ & + & + & + &,-+ &,-+ & + & + & + \\
\hline
\end{tabular}

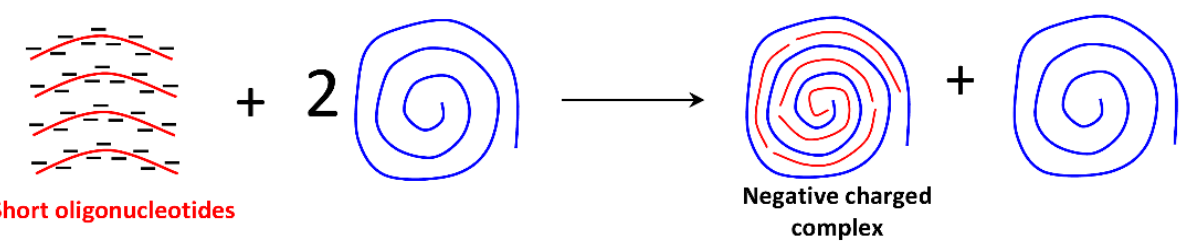

(b)

Scheme 2. Interaction of long (a) and short (b) oligonucleotides with polymeric amine.

Table 3. Types of complexes observed in DNA-polymer interactions $(\mathrm{pH}=7.4)^{1}$.

1 "N"-no interaction; "-"-a diffuse spot in negative area; "+"-neutral or slightly positive band.

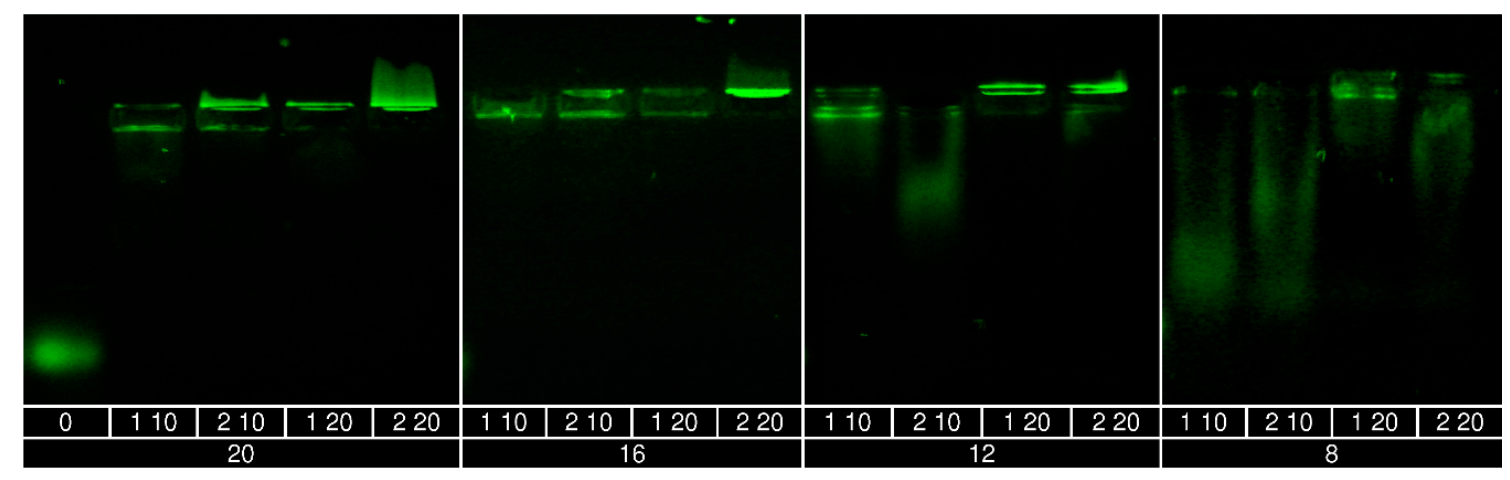

Figure 2. Gel electrophoresis data for PEI (1) and AKX-182 (2) complexes with duplex DNA (last row-length of the DNA), "0"-free DNA (similar blots were observed irrespective of DNA length). DNA concentration was $2.5 \mu \mathrm{M}$ (calculating on DNA chains), N/P ratio presented as the second number in first row. 


\subsection{Synthesis of Poly(N,N-dimethylacrylamide) with Grafted LCPA Chains}

The desired PDMAAm with grafted LCPA chains was synthesized starting from poly(acryloyl chloride) which was converted into PDMAAm containing activated acrylic ester (oxysuccinimide) units. This copolymer was fractionated by precipitation from $\mathrm{CH}_{2} \mathrm{Cl}_{2}$ with n-hexane. The mixture of LCPA oligomers was fractionated with flash-SEC and three fractions containing oligomers with average 13, 16 and 27 nitrogen atoms were obtained. These oligomers as well as anon-fractioned sample were involved in the reaction with activated polymer, giving rise to the target polymers (Scheme 3, Table 2). The grafting degree of the LCPA chains is 1.8-3.4, $\mathrm{M}_{\mathrm{w}} / \mathrm{M}_{\mathrm{n}}$ ratio is 1.16-1.24 for polymers with fractionated LCPA chains which is significantly lower than the values for polymers based on poly(acryloyl chloride) without fractionation (1.37-1.58 [21]).

\subsection{Interaction of LCPA Containing Polymers with Oligonucleotides}

Complexation between PDMAAm with grafted LCPA and oligonucleotides was studied with gel electrophoresis (Figure 3). The AKX-371-5 sample only interacts with 16-24-mer DNA N/P = 20 . The other polymers yield complexes at N/P $>40$. This behaviour corresponds to the data with PEI and AKX-182 samples: AKX-371-5 contains long ( $>16$ units) side polyamine chains and all these chains exceed the critical length for interaction with DNA. AKX-371-1 (LCPA chain length-13.4) is not active in the complexation because the LCPA chain is not sufficient for the reaction with DNA and stacking structures from several LCPA chains are not possible due to the low grafting degree. AKX-371-2 and AKX-371-3 contain a certain fraction of LCPA longer than 20 units and an increase in the polymer concentration results in approximately full complexation at $\mathrm{N} / \mathrm{P}=150$.<smiles>CCN(CC)CC(C)C(C)C(C)C(C)C(=O)ON1C(=O)CCC1=O</smiles><smiles>[R15]CCCCC(C)C(=O)ON1C(=O)CCC1=O</smiles>

Fractions of ZS-358

Scheme 3. Synthesis of poly( $N, N$-dimethylacrylamide $)$ with grafted LCPA chains.

Interaction of the polymers with 19-mer double stranded si-RNA against vascular endothelial growth factor (VEGF) was studied with RiboGreen assay [44] which allows us to measure the concentration of free, non-complexed RNA (Table 4). The most stable complexes were obtained with the ZS-371-5 polymer and the complexation proceeds to a large degree at N/P ratio 20, which corresponds to formation of partially negatively charged complexes.

DLS data (Figure 4) show the presence of ZS-371-1, ZS-371-2 and ZS-371-3 macromolecules in a non-aggregated state, $R_{h}=3-4 \mathrm{~nm}$ is close to the size of other polymers based on PAC [45]. Interaction with nucleic acid results in the formation of aggregates, especially in the case of ZS-371-2 and ZS-371-3. The ZS-371-1 polymer forms smaller aggregates probably because short LCPA chains 
cannot compensate the negative charge of siRNA, which is confirmed with $\zeta$-potential data. ZS-371-5 exists in the form of $50 \mathrm{~nm}$ aggregates and complexation with siRNA does not influence the particle size. We can hypothesize that siRNA chains interact with LCPA chains of comparable length without changing the aggregate structure. TEM (Figure 5) and AFM (Figure 6) data qualitatively agree with DLS data. The larger size values obtained with DLS are explainable with swelling of the macromolecules and association with hydrated counterions. In any case, complexes of the LCPA containing polymers with oligonucleotides exist as 100-200 $\mathrm{nm}$ particles (Figure 4) which is appropriate for internalization into living cells [46-48].

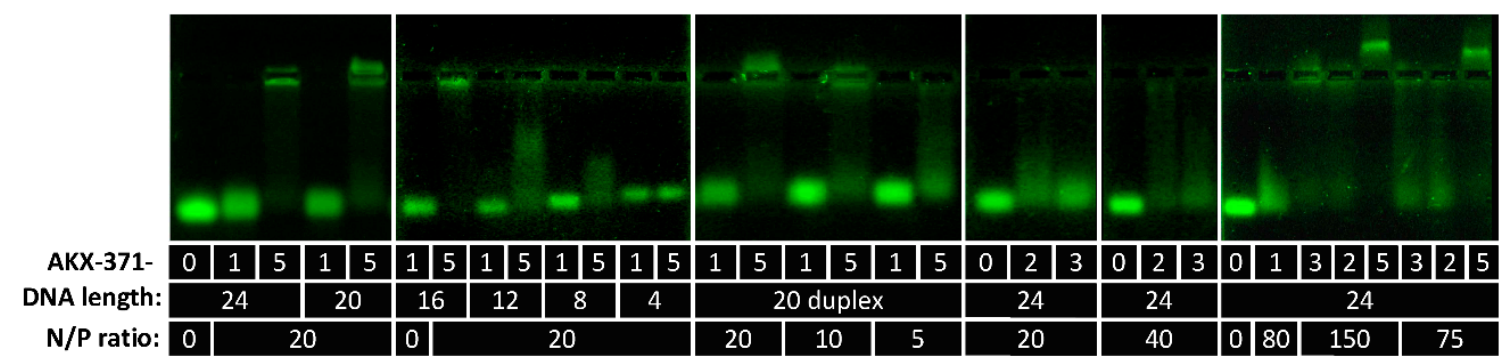

Figure 3. Gel electrophoresis data for AKX-371-N $(\mathrm{N}=1,2,3,5)$ complexes with DNA. "0"-free DNA (similar blots were observed irrespective of DNA length). DNA concentration was $2.5 \mu \mathrm{M}$ (calculating on DNA chains).

Table 4. Interaction of si-RNA with LCPA containing polymers.

\begin{tabular}{ccc}
\hline Polymer & N/P Ratio & Free RNA, $\%$ \\
\hline ZS-371-1 & 20 & 6.4 \\
ZS-371-2 & 20 & 5.6 \\
ZS-371-3 & 20 & 11.9 \\
ZS-371-5 & 20 & 3.8 \\
ZS-371-1 & 80 & 8.9 \\
ZS-371-2 & 150 & 5.8 \\
ZS-371-3 & 155 & 7.4 \\
ZS-371-5 & 180 & 5.3 \\
\hline
\end{tabular}

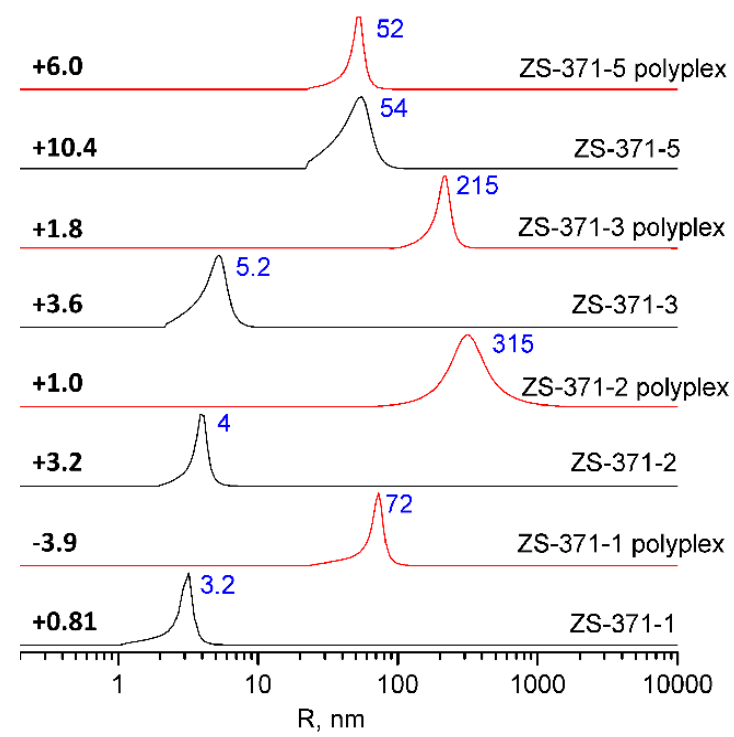

Figure 4. Dynamic light scattering (DLS) data (volume \% vs. $\mathrm{R}_{\mathrm{h}}$ ) for the polymers and polyplexes. Numbers at the left side- $\zeta$-potential values. Initial polymer concentration was $4 \mathrm{mg} / \mathrm{mL}$, siRNA-10 $\mu \mathrm{M}$ with a polymer to siRNA ratio of 4:1 which corresponds to the conditions of the in vitro experiments. 


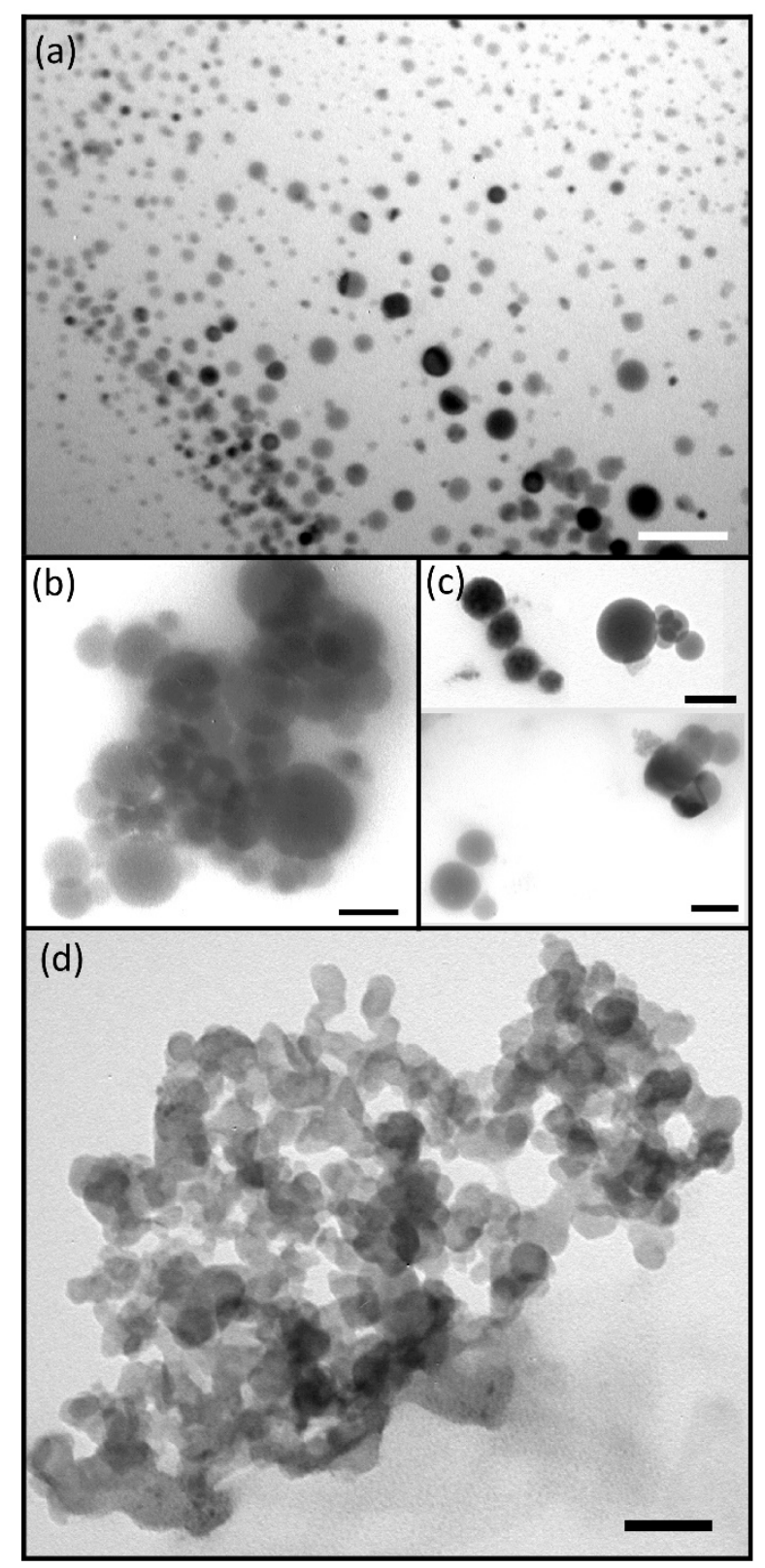

Figure 5. Transmission electron microscopy (TEM) images of the polymer-double strand 20-mer DNA. (a) ZS-371-1; (b) ZS-371-2; (c) ZS-371-3; and (d) ZS-371-5 polymers. Initial polymer concentration was $4 \mathrm{mg} / \mathrm{mL}$, siRNA-10 $\mu \mathrm{M}$ with a polymer to DNA ratio of 4:1 (volume to volume) which corresponds to the conditions of in vitro experiments. Scale bar represents $100 \mathrm{~nm}$. 


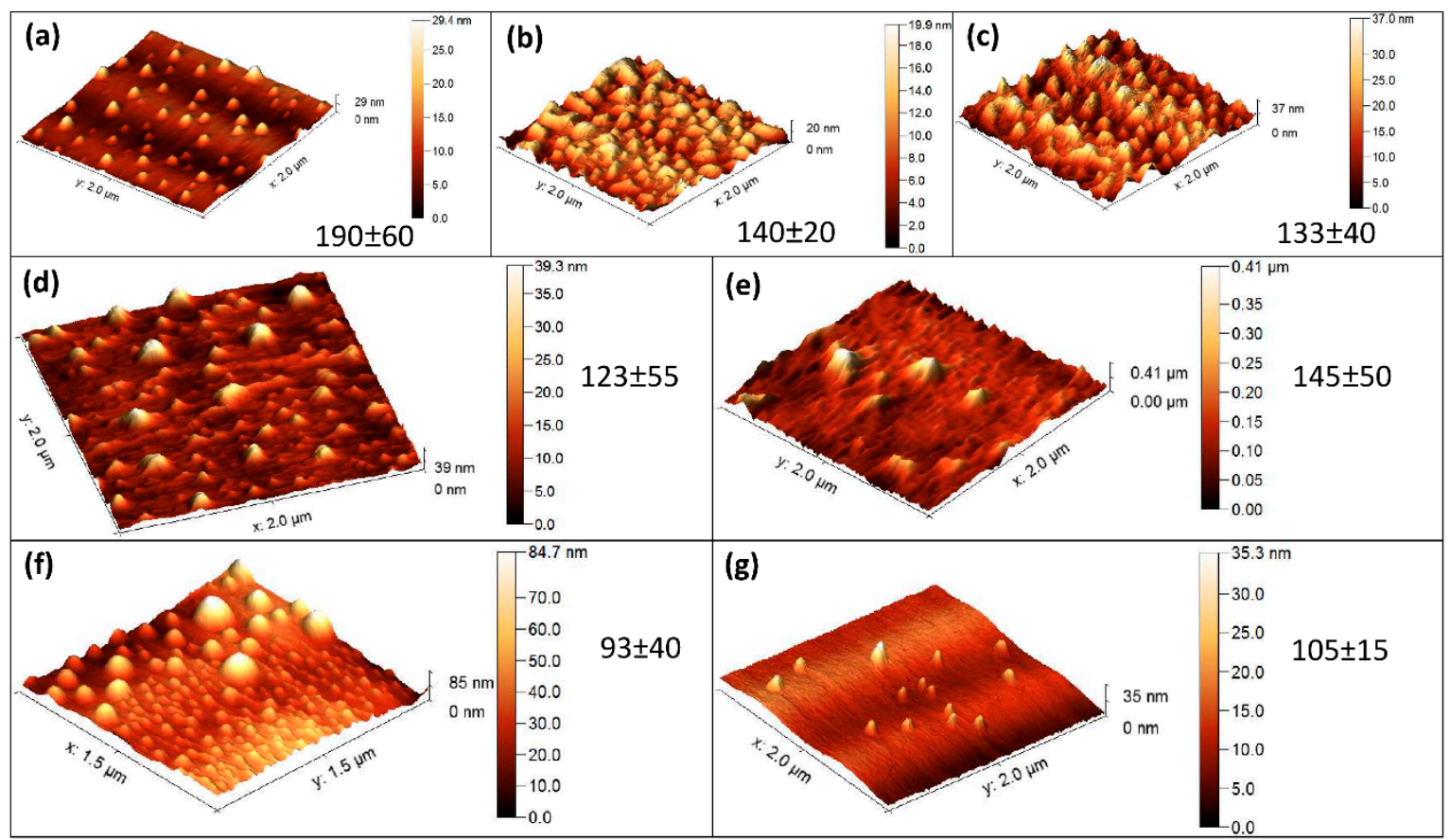

Figure 6. AFM images of AKX-371-5 polymer (a), complexes of polymers AKX-371-5 (b,c), AKX-371-2 $(\mathbf{d}, \mathbf{e})$ and AKX-371-3 (f,g) with single strand $(\mathbf{b}, \mathbf{d}, \mathbf{f})$ and double strand $(\mathbf{c}, \mathbf{e}, \mathbf{g})$ 20-mer DNA. N/P ratios are $180(\mathbf{b}, \mathbf{c}), 150(\mathbf{d}, \mathbf{e})$ and 155 (f,g). AKX-371-1 did not give particles appropriate for AFM study. Numbers near pictures present average sizes of the particles, $\mathrm{nm}$.

\subsection{In Vitro Study of Transfection Activity of si-RNA Polyplexes Based on LCPA Containing Polymers}

The new polymeric amines were studied as transfection agents with the use of 19-mer si-RNA which can silence vascular endothelial growth factor (VEGF) [49]. Viability (Figure 7) and internalization assays (Figure 8) were performed to estimate the transfection potential of the new polymers.

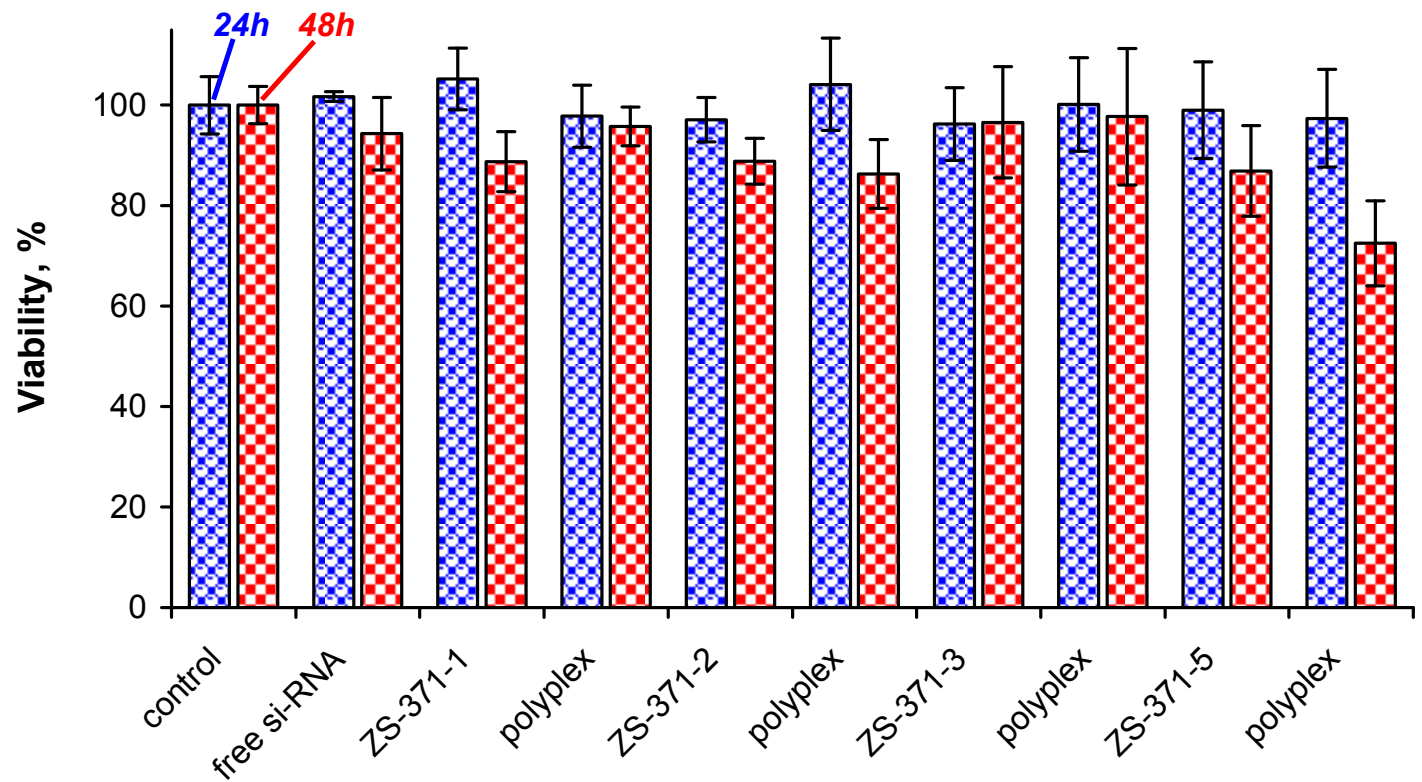

Figure 7. Cell viability of A549 cancer cells after treatment with different polymers both independently as well as after complexation with anti-VEGF si-RNA. Data represent mean $\pm \operatorname{SD}\left({ }^{*} p<0.05, \mathrm{n}=5\right)$. 


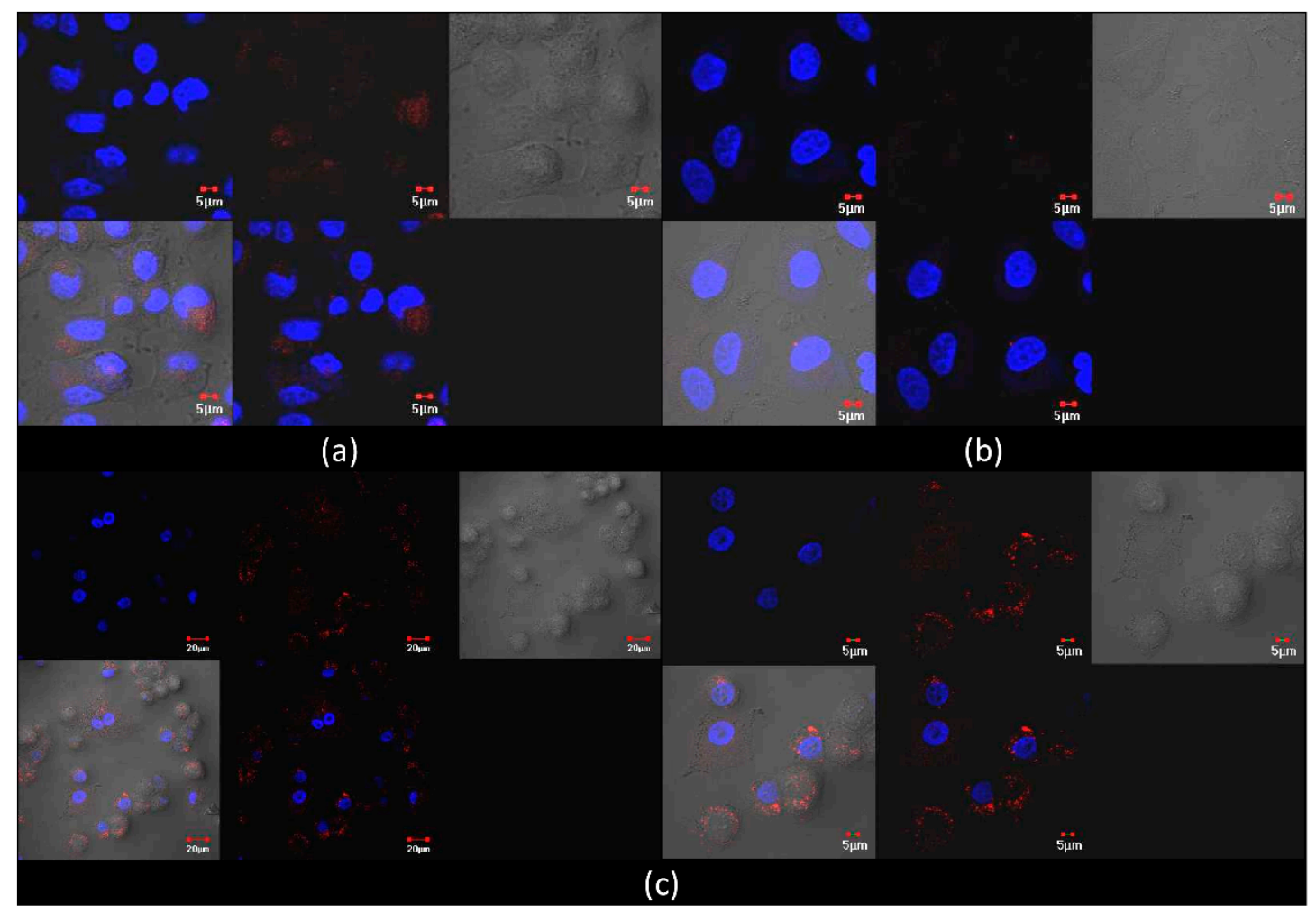

Figure 8. Internalization of polyplexes based on ZS-371-3 (a) and ZS-371-5 (b,c) polymers in A549 cancer cells after $4(\mathbf{a}, \mathbf{b})$ and 6 (c) h observed using laser scanning confocal microscopy. Scale bar represents 5 (a-c, right) and 25 (c, left) $\mu \mathrm{m}$.

The free siRNA does not show significant reduction in viability after $24 \mathrm{~h}$ as well as after $48 \mathrm{~h}$. The free ZS-371-1 shows a slight but insignificant decrease in the viability of the A-549 cells after $48 \mathrm{~h}$ but its complex with anti-VEGF siRNA does not show any toxicity after both time points. This suggests that the surface charges on the uncomplexed polymer may interfere with the viability of the proliferating cells. Complexation with the siRNA neutralizes the surface charges that are manifested in the absence of any marked decrease in the cell viability after $48 \mathrm{~h}$. The ZS-371-2 polymer does not alter the viability at both time points, indicating its lack of toxicity. However, its polyplex with siRNA shows a slight reduction in the viability after $48 \mathrm{~h}$. This suggests an effect of the VEGF silencing on different signalling pathways in the polyplex treated cells. In comparison, the ZS-371-3 did not alter the cell viability after $24 \mathrm{~h}$ or $48 \mathrm{~h}$ both in the uncomplexed as well as complexed forms. This may arise due to poor internalization into the cells or due to poor complexation or extremely high affinity complexation that restricts the release of the siRNA or due to poor ability to escape from the endosome. However, the internalization studies (Figure 8a) show that the ZS-371-3 polyplex localizes rapidly within $4 \mathrm{~h}$ in the cells, thereby ruling out the possibility of poor internalization. Further, ribogreen assay reveals that the complexation efficiency is about $92 \%$ and hence poor siRNA could not explain the observed cell viability. Therefore, it could be possible that the siRNA release or endosomal escape may be the factors that could have influenced the lack of toxicity for this formulation. The viability of cells treated with ZS-371-5 shows a small but insignificant reduction in the viability after $48 \mathrm{~h}$ but its complex with the anti-VEGF siRNA shows a significant decrease in the cell viability after $48 \mathrm{~h}$, indicating the effect of VEGF silencing in the cells. Several reports [50,51] have indicated that VEGF silencing can mediate cell death and decreased proliferation by modulating the PI3K/Akt and Notch signalling pathways, respectively. Internalization studies show (Figure 8b) significant internalization of si-RNA after 6h. siRNA localizes mostly in cytoplasm (not in nucleus) which is necessary for effective silencing. The ribogreen assay revealed that ZS-371-5 shows the maximum complexation efficiency followed by the ZS-371-2 which is explainable with the length of the grafted LCPA chains. This could be one of the 
factors that could have influenced the cell viability assay. Additional factors such as endosomal escape and release of siRNA, which could also have influenced the viability, need further validation.

The VEGF silencing efficiency of the polyplexes was evaluated using Western blot and the results are presented in Figure 9. Though all polyplexes show a reduction in the VEGF band intensity when compared with the untreated control cells, the maximum reduction in the VEGF band intensity was observed for ZS-371-5 polyplex while the least reduction was observed for ZS-371-1. Upon normalizing the band intensities with beta actin, the maximum silencing efficiency was obtained for ZS-371-5 and ZS-371-3 while ZS-371-1 and ZS-371-2 showed lesser silencing efficiency. Thus, the loss in viability observed in A549 lung cancer cells treated with the polyplex ZS-371-5 may be attributed to a direct consequence of its VEGF silencing ability.

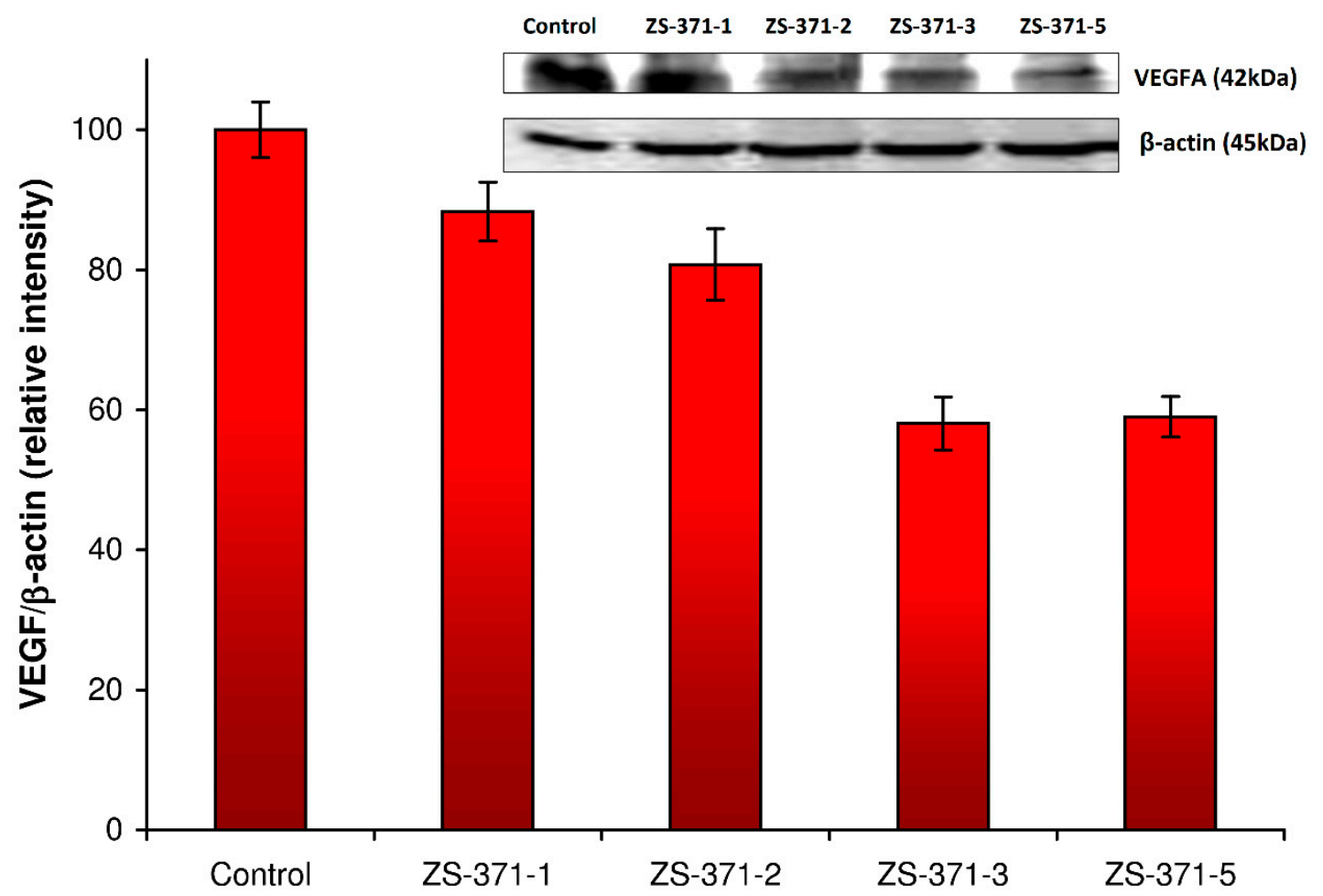

Figure 9. Western blot study of VEGF silencing in A549 cancer cells after $24 \mathrm{~h}$. Data represent mean $\pm \mathrm{SD}\left({ }^{*} p<0.05, \mathrm{n}=4\right)$. Insertion demonstrates a typical membrane image after visualization of the proteins.

\section{Conclusions}

We have found that the critical length for oligonucleotides in interaction with polymeric amines is $8-12$ units and complexation at these lengths can be accompanied by "all-or-nothing" effects. New polymers with grafted polyamine chains were obtained and studied in complexation with DNA and RNA oligonucleotides. The most effective interaction, transfection activity and VEGF silencing efficiency was found for a sample with an average number of nitrogens in polyamine chain equal to 27 , i.e., for a sample in which all grafted chains are longer the critical length for polymeric amine-oligonucleotide complexation.

Supplementary Materials: The following are available online at http:/ / www.mdpi.com/2073-4360/10/12/1297/ s1, Figure S1. Liquid chromatography-mass spectrometry (LC-MS) analysis of ZS-309 fractions; Figure S2. 1H NMR spectra of LCPA (ZS-309) fractions.; Figure S3 1H NMR spectra of copolymers (derivatized with TFA) in DMSO-d6.

Author Contributions: V.V.A. conceived and designed the experiments on polymer synthesis and the study of polymer-DNA interactions; U.M.K. conceived and designed the experiments on polymer-si-RNA interaction and the in vitro study of the polyplexes; E.N.D. performed experiments in the study of polymer-DNA interactions 
and analyzed the data; V.A.P. and S.N.Z. performed synthesis of new polymers; G.K. performed the experiments on polymer-si-RNA interaction and the in vitro study of the polyplexes; and V.V.A. and U.M.K. wrote the paper.

Funding: We acknowledge financial support from a joint grant of the Russian Science Foundation (16-45-02001) and the Department of Science Technology of the Ministry of Science and Technology of the Republic of India (INT/RUS/RSF/10).

Acknowledgments: We are thankful to the Center of Ultramicroanalysis (Limnological Institute) and the Baikal Analytical Center (A. E. Favorsky Irkutsk Institute of Chemistry) for providing equipment.

Conflicts of Interest: The authors declare no conflict of interest.

\section{References}

1. Innus, M. Antisense cancer therapy: Do antisense oligonucleotides hold promise as a cure for cancer? Chem. Sci. J. 2017, 8, e117. [CrossRef]

2. Zaimy, M.; Saffarzadeh, N.; Mohammadi, A.; Pourghadamyari, H.; Izadi, P.; Sarli, A.; Moghaddam, L.; Paschepari, S.; Azizi, H.; Torkamandi, S.; et al. New methods in the diagnosis of cancer and gene therapy of cancer based on nanoparticles. Cancer Gene Ther. 2017, 24, 233-243. [CrossRef] [PubMed]

3. Gurav, B.; Srinivasan, G. Antisense oligonucleotides as therapeutics and their delivery. Curr. Sci. 2017, 112, 490-498. [CrossRef]

4. Bhavsar, D.; Subramanian, K.; Sethuraman, S.; Krishnan, U.M. Nano-in-nano' hybrid liposomes increase target specificity and gene silencing efficiency in breast cancer induced SCID mice. Eur. J. Pharm. Biopharm. 2017, 119, 96-106. [CrossRef] [PubMed]

5. Behr, J.P. The proton sponge: A trick to enter cells the viruses did not exploit. Chimia 1997, 51, 34-36.

6. Akinc, A.; Thomas, M.; Klibanov, A.M.; Langer, R. Exploring polyethylenimine-mediated DNA transfection and the proton sponge hypothesis. J. Gene Med. 2005, 7, 657-663. [CrossRef] [PubMed]

7. Liu, S.; Zhou, D.; Yang, J.; Zhou, H.; Chen, J.; Guo, T. Bioreducible Zinc(II)-coordinative polyethylenimine with low molecular weight for robust gene delivery of primary and stem cells. J. Am. Chem. Soc. 2017, 139, 5102-5109. [CrossRef] [PubMed]

8. Cutlar, L.; Gao, Y.; Aied, A.; Greiser, U.; Murauer, E.M.; Zhou, D.; Wang, W. A knot polymer mediated non-viral gene transfection for skin cells. Biomater. Sci. 2016, 4, 92-95. [CrossRef] [PubMed]

9. Sun, Z.; Zhou, D. PLL/PAE/DNA ternary complexes with enhanced endosomal escape ability for efficient and safe gene transfection. New J. Chem. 2016, 40, 9806-9812. [CrossRef]

10. Liu, S.; Gao, Y.; Sigen, A.; Zhou, D.; Greiser, U.; Guo, T.; Guo, R.; Wang, W. Biodegradable highly branched poly( $\beta$-amino ester)s for targeted cancer cell gene transfection. ACS Biomater. Sci. Eng. 2017, 3, 1283-1286. [CrossRef]

11. Zhou, D.; Gao, Y.; Aiedb, A.; Cutlar, L.; Igoucheva, O.; Newland, B.; Alexeeve, V.; Greiser, U.; Uitto, J.; Wang, W. Highly branched poly( $\beta$-amino ester)s for skin gene therapy. J. Control. Release 2016, 244, 336-346. [CrossRef] [PubMed]

12. Gao, Y.; Huang, J.-Y.; O'Keeffe Ahern, J.; Cutlar, L.; Zhou, D.; Lin, F.-H.; Wang, W. Highly branched poly ( $\beta$-amino esters) for non-viral gene delivery: High transfection efficiency and low toxicity achieved by increasing molecular weight. Biomacromolecules 2016, 17, 3640-3647. [CrossRef] [PubMed]

13. Zhou, D.; Cutlar, L.; Gao, Y.; Wang, W.; O’Keeffe-Ahern, J.; McMahon, S.; Duarte, B.; Larcher, F.; Rodriguez, B.J.; Greiser, U.; et al. The transition from linear to highly branched poly( $\beta$-amino ester)s: Branching matters for gene delivery. Sci. Adv. 2016, 2, e1600102. [CrossRef] [PubMed]

14. Liu, S.; Yang, J.; Ren, H.; O’Keeffe-Ahern, J.; Zhou, D.; Zhou, H.; Chen, J.; Guo, T. Multifunctional oligomer incorporation: A potent strategy to enhance the transfection activity of poly(L-lysine). Biomater. Sci. 2016, 4, 522-532. [CrossRef] [PubMed]

15. Tsuchida, E.; Abe, K. Interactions between macromolecules in solution and intermacromolecular complexes. Adv. Polym. Sci. 1982, 45, 1-119. [CrossRef]

16. Antipina, A.D.; Baranovskii, V.Y.; Papisov, I.M.; Kabanov, V.A. Equilibrium peculiarities in the complexing of polymeric acids with poly (ethylene glycols). Polym. Sci. U.S.S.R. 1972, 14, 1047-1057. [CrossRef]

17. Dufresne, M.H.; Elsabahy, M.; Leroux, J.C. Characterization of polyion complex micelles designed to address the challenges of oligonucleotide delivery. Pharm. Res. 2008, 25, 2083-2093. [CrossRef] [PubMed] 
18. Sparks, S.M.; Waite, C.L.; Harmon, A.M.; Nusblat, L.M.; Roth, C.M.; Uhrich, K.E. Efficient intracellular siRNA delivery by ethyleneimine-modified amphiphilic macromolecules. Macromol. Biosci. 2011, 11, 1192-1200. [CrossRef] [PubMed]

19. Maassen, S.J.; de Ruiter, M.V.; Lindhoud, S.; Cornelissen, J.J.L.M. Oligonucleotide length dependent formation of virus-like particles. Chem. Eur. J. 2018, 24, 7456-7463. [CrossRef] [PubMed]

20. Wadhwa, M.S.; Collard, W.T.; Adami, R.C.; McKenzie, D.L.; Rice, K.G. Peptide-mediated gene delivery: Influence of peptide structure on gene expression. Bioconj. Chem. 1997, 8, 81-88. [CrossRef] [PubMed]

21. Danilovtseva, E.; Maheswari Krishnan, U.; Pal'shin, V.; Annenkov, V. Polymeric amines and ampholytes derived from poly(acryloyl chloride): Synthesis, influence on silicic acid condensation and interaction with nucleic acid. Polymers 2017, 9, 624. [CrossRef]

22. Annenkov, V.V.; Krishnan, U.M.; Pal'shin, V.A.; Zelinskiy, S.N.; Kandasamy, M.; Danilovtseva, E.N. Bioinspired water-soluble polymers with grafted polyamine chains: Synthesis and complexation with oligonucleotides. Chin. J. Polym. Sci. 2018, 36, 1114-1122. [CrossRef]

23. Pegg, A.E. The function of spermine. IUBMB Life 2014, 66, 8-18. [CrossRef] [PubMed]

24. Knott, J.M. Biosynthesis of long-chain polyamines by crenarchaeal polyamine synthases from Hyperthermus butylicus and Pyrobaculum aerophilum. FEBS Lett. 2009, 583, 3519-3524. [CrossRef] [PubMed]

25. Kröger, N.; Deutzmann, R.; Bergsdorf, C.; Sumper, M. Species-specific polyamines from diatoms control silica morphology. Proc. Natl. Acad. Sci. USA 2000, 97, 14133-14138. [CrossRef] [PubMed]

26. Matsunaga, S.; Sakai, R.; Jimbo, M.; Kamiya, H. Long-chain polyamines (LCPAs) from marine sponge: Possible implication in spicule formation. ChemBioChem 2007, 8, 1729-1735. [CrossRef] [PubMed]

27. Durak, G.M.; Taylor, A.R.; Walker, C.E.; Probert, I.; de Vargas, C.; Audic, S.; Schroeder, D.; Brownlee, C.; Wheeler, G.L. A role for diatom-like silicon transporters in calcifying coccolithophores. Nat. Commun. 2016, 7, 10543. [CrossRef] [PubMed]

28. Kroger, N.; Deutzmann, R.; Sumper, M. Polycationic peptides from diatom biosilica that direct silica nanosphere formation. Science 1999, 286, 1129-1132. [CrossRef] [PubMed]

29. Annenkov, V.V.; Shishlyannikova, T.A.; Zelinskiy, S.N.; Bridoux, M.C.; Danilovtseva, E.N. Unusual polyamines from Baikalian diatoms. ChemistrySelect 2018, 3, 9708-9713. [CrossRef]

30. Brunner, E.; Lutz, K.; Sumper, M. Biomimetic synthesis of silica nanospheres depends on the aggregation and phase separation of polyamines in aqueous solution. Phys. Chem. Chem. Phys. 2004, 6, 854-857. [CrossRef]

31. Annenkov, V.V.; Danilovtseva, E.N.; Pal'shin, V.A.; Aseyev, V.O.; Petrov, A.K.; Kozlov, A.S.; Patwardhan, S.V.; Perry, C.C. Poly (vinyl amine)—Silica composite nanoparticles: Models of the silicic acid cytoplasmic pool and as a silica precursor for composite materials formation. Biomacromolecules 2011, 12, 1772-1780. [CrossRef] [PubMed]

32. Annenkov, V.V.; Zelinskiy, S.N.; Danilovtseva, E.N.; Perry, C.C. Synthesis of biomimetic polyamines. Arkivoc 2009, 2009, 116-130. [CrossRef]

33. Annenkov, V.V.; Pal'shin, V.A.; Verkhozina, O.N.; Larina, L.I.; Danilovtseva, E.N. Composite nanoparticles: A new way to siliceous materials and a model of biosilica synthesis. Mater. Chem. Phys. 2015, 165, 227-234. [CrossRef]

34. Annenkov, V.V.; Patwardhan, S.V.; Belton, D.; Danilovtseva, E.N.; Perry, C.C. A new stepwise synthesis of a family of propylamines derived from diatom silaffins and their activity in silicification. Chem. Commun. 2006, 1521-1523. [CrossRef] [PubMed]

35. Pavlov, G.M.; Korneeva, E.V.; Ebel, C.; Gavrilova, I.I.; Nesterova, N.A.; Panarin, E.F. Hydrodynamic behavior, molecular mass and conformational parameters of poly(vinylformamide) molecules. Polym. Sci. A 2004, 46, 1063-1067.

36. Buruiana, E.C.; Buruiana, T.; Hahui, L. Preparation and characterization of new optically active poly(N-acryloyl chloride) functionalized with (S)-phenylalanine and pendant pyrene. J. Photochem. Photobiol. A 2007, 189, 65-72. [CrossRef]

37. Newman, S.; Krigbaum, W.R.; Laugier, C.; Flory, P.J. Molecular dimensions in relation to intrinsic viscositie. J. Polym. Sci. 1954, 14, 451-462. [CrossRef]

38. Farnsworth, N.R. Biological and phytochemical screening of plants. J. Pharm. Sci. 1966, 55, $225-276$. [CrossRef] [PubMed]

39. Liu, Q.; Zhu, M. Determination of molar ratio of primary secondary and tertiary amines in polymers by applying derivatization and NMR spectroscopy. Polym. Test. 2016, 56, 174-179. [CrossRef] 
40. Kondinskaia, D.A.; Gurtovenko, A.A. Supramolecular complexes of DNA with cationic polymers: The effect of polymer concentration. Polymer 2018, 142, 277-284. [CrossRef]

41. Shen, Z.L.; Xia, Y.Q.; Yang, Q.S.; Tian, W.D.; Chen, K.; Ma, Y.Q. Polymer-nucleic acid interactions. Top. Curr. Chem. 2017, 375, 44. [CrossRef] [PubMed]

42. Lopez-Fontal, E.; Milanesi, L.; Tomas, S. Multivalence cooperativity leading to "all-or-nothing" assembly: The case of nucleation-growth in supramolecular polymers. Chem. Sci. 2016, 7, 4468-4475. [CrossRef] [PubMed]

43. Li, Y.; Zhao, T.; Wang, C.; Lin, Z.; Huang, G.; Sumer, B.D.; Gao, J. Molecular basis of cooperativity in pH-triggered supramolecular self-assembly. Nat. Commun. 2016, 7, 13214. [CrossRef] [PubMed]

44. Michel, T.; Luft, D.; Abraham, M.K.; Reinhardt, S.; Medina, M.L.S.; Kurz, J.; Schaller, M.; Avci-Adali, M.; Schlensak, C.; Peter, K.; et al. Cationic nanoliposomes meet mRNA: Efficient delivery of modified mRNA using hemocompatible and stable vectors for therapeutic applications. Mol. Ther. Nucleic Acids 2017, 8, 459-468. [CrossRef] [PubMed]

45. Zakharova, N.V.; Simonova, M.A.; Khairullin, A.R.; Filippov, A.P.; Danilovtseva, E.N.; Zelinskii, S.N.; Annenkov, V.V. Effect of $\mathrm{pH}$ on the behavior of a random copolymer of acrylamide. Polym. Sci. A 2018, 60, 127-133. [CrossRef]

46. Wang, W.; Naolou, T.; Ma, N.; Deng, Z.; Xu, X.; Mansfeld, U.; Wischke, C.; Gossen, M.; Neffe, A.T.; Lendlein, A. Polydepsipeptide block-stabilized polyplexes for efficient transfection of primary human cells. Biomacromolecules 2017, 18, 3819-3833. [CrossRef] [PubMed]

47. Kasper, J.C.; Schaffert, D.; Ogris, M.; Wagner, E.; Friess, W. Development of a lyophilized plasmid/LPEI polyplex formulation with long-term stability-A step closer from promising technology to application. J. Control. Release 2011, 151, 246-255. [CrossRef] [PubMed]

48. Pezzoli, D.; Giupponi, E.; Mantovani, D.; Candiani, G. Size matters for in vitro gene delivery: Investigating the relationships among complexation protocol, transfection medium, size and sedimentation. Sci. Rep. 2017, 7, 44134. [CrossRef] [PubMed]

49. Espana-Serrano, L.; Chougule, M.B. Enhanced anticancer activity of PF-04691502, a dual PI3K/mTOR inhibitor, in combination with VEGF siRNA against non-small-cell lung cancer. Mol. Ther. Nucleic Acids 2016, 5, e384. [CrossRef] [PubMed]

50. Peng, N.; Gao, S.; Guo, X.; Wang, G.; Cheng, C.; Li, M.; Liu, K. Silencing of VEGF inhibits human osteosarcoma angiogenesis and promotes cell apoptosis via VEGF/PI3K/AKT signaling pathway. Am. J. Transl. Res. 2016, 8, 1005-1015. [PubMed]

51. Li, G.J.; Yang, Y.; Yang, G.K.; Wan, J.; Cui, D.L.; Ma, Z.H.; Du, L.J.; Zhang, G.M. Slit2 suppresses endothelial cell proliferation and migration by inhibiting the VEGF-Notch signaling pathway. Mol. Med. Rep. 2017, 15, 1981-1988. [CrossRef] [PubMed]

(c) 2018 by the authors. Licensee MDPI, Basel, Switzerland. This article is an open access article distributed under the terms and conditions of the Creative Commons Attribution (CC BY) license (http://creativecommons.org/licenses/by/4.0/). 